\begin{tabular}{ccc}
\hline International Journal of Engineering \& Technology \\
SPC \\
Website: www.sciencepubco.com/index.php/IJET \\
Research paper
\end{tabular}

\title{
Technology of Molding Masses for Architectural and Artistic Ceramics Using Low-Aluminate Clays
}

\author{
Nina Chopenko $^{1 *}$; Vladimir Muravlev², Olga Skorodumova ${ }^{3}$ \\ ${ }^{1}$ Poltava National Technical University Named After Yuri Kondratyuk, Ukraine \\ ${ }^{2}$ Poltava National Technical University Named After Yuri Kondratyuk, Ukraine \\ ${ }^{3}$ National University Of Civil Defense Of Ukraine, Ukraine \\ *Corresponding Author E-Mail: Nina_Chopenko@Ukr.Net
}

\begin{abstract}
The article deals with the main technological problems arising in the manufacture of large-scale ceramic products for architectural and artistic purposes. The influence of low-burned chamotte obtained from low-alumina clay on the physical and mechanical properties of molding masses based on the Oposhnya clays is investigated. It is shown that the firing medium of the developed molding masses significantly affects the properties of ceramic products.
\end{abstract}

Keywords: Architectural and artistic ceramics, dehydrated clay, low-aluminate clays, mullite, chamotte, chamotte masses.

\section{Introduction}

With the expansion of individual construction, ceramic products of architectural and artistic use are becoming more and more popular. Architectural and artistic ceramics in the form of art panels, figured blocks, polycircular niches with stucco decorations, balustrades, balusters with capitals, decorative vases, moldings, cornices, etc., are increasingly used in interiors and exteriors of new civil and religious buildings, in the reconstruction and restoration of old buildings.

Increasing the consumption of architectural and artistic ceramic products causes an increase in the volume of their production, which, in turn, creates a deficit of high-quality clay raw materials, since high-grade refractory high-plastic clays must be used to achieve high physical and mechanical characteristics of products. Unfortunately, at present there are no data on specially developed masses for large-sized products. In general, standard nonshrinkage compounds for ceramic products with high strength characteristics are used.

The manufacture of large-sized ceramic products requires the following requirements for molding masses:

- the possibility of high-quality plastic molding by hand of ceramic products of complex shape and large dimensions; -provision of high strength characteristics of the molded raw materials of a large mass for safe transportation for drying;

-provision of sufficient strength characteristics of the dried products for safe transportation and pumping into the baking oven; -low shrinkage during drying and roasting;

-provision of the possibility of qualitative decorating of products after firing;

-possibility to use a wide range of low-temperature paints, engobes and glazes in decoration;

-provision of high operational properties of finished ceramic products.

\section{The Experimental}

In Ukraine, there are many deposits of secondary polymineral clays, one of the most promising in terms of capacity is the Oposhnya deposit (Poltava region). The results of a complex investigation of the Oposhnya deposit clays are presented in $[1,2]$ : their chemical and mineralogical compositionis determined, structural and mechanical characteristics, the temperature interval for sintering of pure clays and in mixtures with high alumina refractory clays are determined, the features of their behavior in firing are clarified, charge for chamotte is elaborated [3].

The aim of this work is to develop a technology for chamotte molding masses for architectural and artistic ceramic products using non-deficient low-aluminate clays.

\subsection{Materials and Methods}

Clays of the Oposhnya deposit of horizons No. 6 and 7, containing 15-19 wt. $\% \mathrm{Al}_{2} \mathrm{O}_{3}$. The refractoriness of the clays studied, calculated by the method of Bezborodov, amounted to 1590 and $1614^{\circ} \mathrm{C}$ for the clays of horizons No. 6 and 7, respectively. Based on the results of X-ray diffraction (X-ray diffractometer DRON $3 \mathrm{M}, \mathrm{CuK \alpha}$ radiation) and petrographic methods (NU-2 polarization microscope), the clay of horizon No. 6 refer to the montmorillonite-kaolinite type, and the clay of horizon No. 7 contains predominantly beidellite. Clays of horizon No. 6 are moderately plastic, and horizon No. 7 - to high-plastic clays (Table 1). The dependence of the fire and total shrinkage of the Oposhnya clays on the roasting temperature is studied. It has been established that only the clay samples of horizon No. 7 have a pronounced interval of sintered state in the range of $940-1060{ }^{\circ} \mathrm{C}$, and clay 6 of the horizon belongs to non-caking clays. 
Table 1: Properties of Oposhnya clays

\begin{tabular}{|c|c|c|c|c|}
\hline $\begin{array}{c}\text { Clay } \\
\text { occurrence } \\
\text { horizon }\end{array}$ & $\begin{array}{c}\text { Linear } \\
\text { shrinkage, \% }\end{array}$ & $\begin{array}{c}\text { Volumetric } \\
\text { shrinkage, \% }\end{array}$ & $\begin{array}{c}\text { Coefficient } \\
\text { sensitivity } \\
\text { to drying }\end{array}$ & $\begin{array}{c}\text { Number of } \\
\text { ductility }\end{array}$ \\
\cline { 2 - 5 } & & & & \\
\hline 6 & 7,5 & 14,19 & 1,76 & 21 \\
\hline 7 & 10,0 & 22,88 & 1,95 & 27 \\
\hline
\end{tabular}

The study of the rheological characteristics of the clays of horizons No. 6 and 7 showed that they belong to the zero structural-mechanical type. Ceramic masses on their basis are well molded by the plastic method and allow the production of largesized products of complex shape without defects.

It is irrational to produce chamotte from pure oposhnian clays, as these clays have a sufficient amount of fusible inclusions, which can cause pyroplastic deformations during firing. The most logical is to use chamotte, obtained on the basis of a mixture of oposhnian clays and non-deficient refractory clays of poor quality.

The sinterability of fine particles of chamotte depends on the mineralogical composition of the clays from which this fireclay is prepared. The smallest particles of chamotte from kaolinitehydromica clays are most active for sintering [4], therefore, in order to obtain improved strength characteristics without increasing the calcination temperature, low-aluminate hydromicakaolinite clay DVK-2 was used in further studies in the composition of weights for chamotte. The chemical composition of clay DVK-2 is presented in Table 2.

Table 2: Chemical composition of clay DVK-2

\begin{tabular}{|c|c|c|c|c|c|c|c|c|c|}
\hline \multirow[b]{2}{*}{ Clay } & \multicolumn{9}{|c|}{ The content of oxides by weight. \% } \\
\hline & $\mathrm{SiO}_{2}$ & $\mathrm{Al}_{2} \mathrm{O}_{3}$ & $\mathrm{TiO}_{2}$ & $\mathrm{Fe}_{2} \mathrm{O}_{3}$ & $\mathrm{MgO}$ & $\mathrm{CaO}$ & $\mathrm{K}_{2} \mathrm{O}$ & $\mathrm{Na}_{2} \mathrm{O}$ & $\begin{array}{c}\text { loss } \\
\text { on } \\
\text { orn }\end{array}$ \\
\hline DVK-2 & 68,00 & 19,00 & 1,80 & 1,30 & 0,6 & 0,4 & 2,50 & 0,5 & 5,8 \\
\hline
\end{tabular}

Mineralogical composition of clay DVK-2 (vol.\%): Kaolinite - 32; illite - 39; quartz - 29; associated minerals <1.

For the production of chamotte according to the traditional technological scheme, the clay was thoroughly mixed, moistened, after which the mixture was briquetted at a pressure of $25 \mathrm{MPa}$ The briquettes were fired at a temperature of $1000{ }^{\circ} \mathrm{C}$ (holding for 1 hour), at a temperature rise rate of $6{ }^{\circ} \mathrm{C} / \mathrm{min}$, cooling the samples together with the furnace.

\section{Results and discussion}

Table 3 presents the compositions and properties of chamotte using clay DWK-2.

Table 3:Composition and physical and mechanical properties of experimental chamotte

\begin{tabular}{|c|c|c|c|c|c|c|c|c|c|c|}
\hline \multirow{3}{*}{ 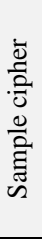 } & \multicolumn{6}{|c|}{ Mineralogical composition, $\%$} & \multicolumn{4}{|c|}{ Properties of chamotte } \\
\hline & \multicolumn{2}{|c|}{$\begin{array}{c}\text { oposhnian } \\
\text { clay }\end{array}$} & \multirow{2}{*}{ 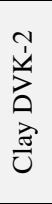 } & \multirow{2}{*}{$\begin{array}{l}\stackrel{\Xi}{\Xi} \\
\stackrel{\Xi}{\Xi} \\
\stackrel{\Xi}{\Xi}\end{array}$} & \multirow[b]{2}{*}{ 兽 } & \multirow{2}{*}{ 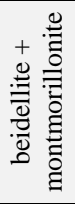 } & \multirow{2}{*}{ 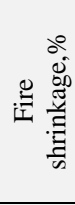 } & \multirow{2}{*}{ 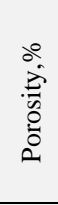 } & \multirow{2}{*}{ 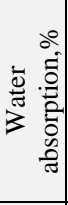 } & \multirow{2}{*}{ 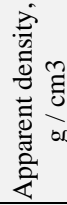 } \\
\hline & № 7 & № 6 & & & & & & & & \\
\hline 1 & - & 50 & 50 & 34,0 & 21,0 & 0,5 & 5,41 & 20,0 & 10,4 & 2,03 \\
\hline 2 & 50 & 25 & 25 & 17,0 & 4,0 & 28,0 & 3,19 & 24,9 & 12,6 & 1.98 \\
\hline 3 & 25 & 50 & 25 & 26,0 & 13,5 & 28,8 & 3,64 & 24,1 & 12,0 & 2,01 \\
\hline 4 & 25 & 30 & 45 & 23,4 & 19,4 & 16,0 & 5,65 & 11,9 & 5,4 & 2,19 \\
\hline
\end{tabular}

Analyzing the effect of the mineralogical composition on the properties of the obtained samples of chamotte (Tables 2 and 3), it can be concluded that the ratio of the content of the main clayforming minerals in the feedstock affects the increase in the strength characteristics of chamotte.

The best indexes have a sample of chamotte No. 4 (Table 3), in which the mineral content is the following (mass\%):

kaolinite group - 23,

illite group - 19 ,

montmorillonite group - 16 .

Experimental samples of chamotte were subjected to grinding and sieving into fractions of $1.25-0.63 \mathrm{~mm}$ and less than $0.63 \mathrm{~mm}$. The molding masses were prepared by mixing two fractions of chamotte with the oposhnian clay at the following ratio (mass\%): chamotte fr.1.25-0.63 mm - 24; chamotte fr. $<0.63 \mathrm{~mm}-36$; oposhnian clay - 40. The charge was moistened with water to a moisture content of $6-8 \%$. Samples of products were pressed at a specific pressure of $25 \mathrm{MPa}$.

As is known [5], art ceramics are fired both in air (in oxidizing medium) and in reducing medium, so the specimens were fired at a temperature of $1000{ }^{\circ} \mathrm{C}$ ( 1 hour), at a temperature rise rate of $6{ }^{\circ} \mathrm{C} / \mathrm{min}$ in oxidizing and reducing environment, cooling with the furnace. Properties of samples of articles obtained by calcination in reducing and oxidizing media are shown in Table. 4 and 5.

Table 4: Properties of art ceramics after firingin a reducing environment

\begin{tabular}{|c|c|c|c|c|c|c|c|}
\hline \multirow[b]{2}{*}{ 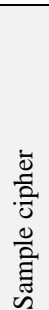 } & \multicolumn{2}{|c|}{$\begin{array}{l}\text { Composition, } \\
\text { mass, } \%\end{array}$} & \multicolumn{5}{|c|}{ Properties } \\
\hline & 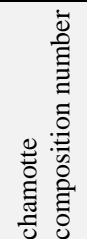 & 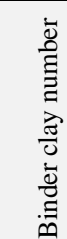 & 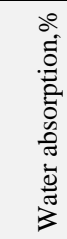 & 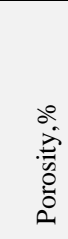 & 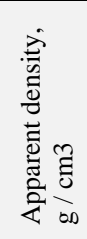 & 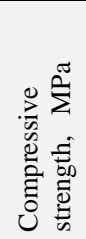 & 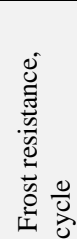 \\
\hline 1 & 1 & 7 & 18,4 & 31,3 & 1,72 & 10,7 & $>35$ \\
\hline 2 & 2 & 7 & 18,4 & 31,6 & 1,72 & 10,2 & $>35$ \\
\hline 3 & 3 & 7 & 16,9 & 29,3 & 1,73 & 10,7 & $>35$ \\
\hline 4 & 4 & 7 & 17,0 & 32,9 & 1,65 & 10,7 & $>35$ \\
\hline 5 & 1 & 6 & 20,4 & 35,8 & 1,72 & 11,3 & $>35$ \\
\hline 6 & 2 & 6 & 19,9 & 34,0 & 1,71 & 7,34 & $>35$ \\
\hline 7 & 3 & 6 & 20,3 & 34,0 & 1,67 & 8,44 & $>35$ \\
\hline 8 & 4 & 6 & 19,3 & 33,0 & 1,71 & 5,65 & $>35$ \\
\hline
\end{tabular}

The fired samples were examined by petrographic analysis. Sample No. 12, calcinated in an oxidizing environment, consists of chamotte particles measuring $1.25-0.2 \mathrm{~mm}$ and a yellowishbrown glass phase containing small, $<4 \mu \mathrm{m}$, mullite crystals. As the accompanying phases in the sample there are quartz, cristobalite, grains of feldspars and accessory minerals, magnetite, hematite, mica flakes (muscovite, biotite).

Table 5: Properties of art ceramics after firingin an oxidizing environment

\begin{tabular}{|c|c|c|c|c|c|c|c|}
\hline \multirow[b]{2}{*}{ 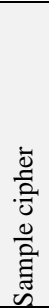 } & \multicolumn{2}{|c|}{$\begin{array}{l}\text { Composition, } \\
\text { mass, } \%\end{array}$} & \multicolumn{5}{|c|}{ Properties } \\
\hline & 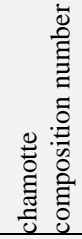 & 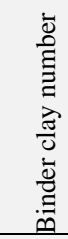 & 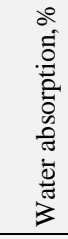 & $\begin{array}{l}0 \\
\grave{0} \\
0 \\
0 \\
0\end{array}$ & 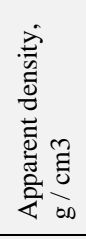 & 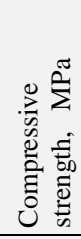 & 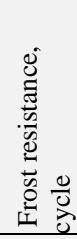 \\
\hline 9 & 1 & 7 & 20,2 & 33,8 & 1,70 & 10,1 & $>35$ \\
\hline 10 & 2 & 7 & 19,0 & 32,4 & 1,71 & 10,2 & $>35$ \\
\hline 11 & 3 & 7 & 18,0 & 31,0 & 1,77 & 10,2 & $>35$ \\
\hline 12 & 4 & 7 & 17,0 & 29,3 & 1,76 & 10,2 & $>35$ \\
\hline 13 & 1 & 6 & 20,8 & - & 1,71 & 7,9 & $>35$ \\
\hline 14 & 2 & 6 & 18,7 & 32,8 & 1,93 & 11,3 & $>35$ \\
\hline 15 & 3 & 6 & 18,3 & 31,4 & 1,78 & 7,3 & $>35$ \\
\hline 16 & 4 & 6 & 18,3 & 31,4 & 1,78 & 8,5 & $>35$ \\
\hline
\end{tabular}

The denser parts of the chamotte are separated by semicircular cracks with a width of 20-200 $\mu \mathrm{m}$. Pores are rare, round, isometric, 4 to 40 in size, to 100 to $750 \mu \mathrm{m}$.

When a reducing medium (sample No. 4) is used, more active crystallization of mullite is observed (the size of acicular mullite crystals is 4-6 $\mu \mathrm{m}$ ), more complete sintering, the number of cracks and their size decreases.

The improvement in strength characteristics in samples burned in a reducing medium can be explained by the fact that the gaseous medium affects the intensity of dehydration of clay minerals during roasting, lowers the dehydration temperature by approximately $100{ }^{\circ} \mathrm{C}$, hence, the sintering processes start at $100{ }^{\circ} \mathrm{C}$ earlier than in oxidative environment, that is, in the reducing environment, intensification of the sintering of the material takes place $[6,7]$. 
The reducing firing medium also favored the reduction of $\mathrm{Fe}^{3+}$ iron in $\mathrm{Fe}^{2+}$. This leads to the early formation of a liquid phase that promotes the course of reactions [8].

\subsection{Influence of Structure on Porosity and Frost Resistance of Large-Sized Products}

The porous-capillary structure of the ceramic product is formed during the molding process and finally during the firing process. When firing ceramic materials made from clays of different chemical and mineralogical composition, pores of various shapes and sizes are formed. A comparison of the porous-capillary structure and frost resistance shows that the frost resistance increases as the ratio of reserve porosity to capillary ratio increases. [9].

The type of the initial porous-capillary structure affects the kinetics of the process of destruction of ceramic products when they are frozen and thawed. Frost resistance increases with the expansion of the range of distribution of effective radius of capillaries, an increase in the ratio of the volumes of reserve porosity and capillary, and a decrease in the content of microcapillaries.

In the presence of pores (both large and small capillaries), the formation of ice occurs in a fairly wide temperature range. If there is a volume of reserve porosity that is not filled with water, then gradually formed ice and supercooled water are squeezed into the space of these pores. The destructive effect of ice in this case is minimal or absent, as a result of which the volumes of total, open and closed porosity change insignificantly or remain constant.

As is known, the amount and properties of the exhausting materials have a significant effect on the speed of drying and roasting, the operational properties of the products. The use of chamotte requires additional costs for its production, the use of quartz sand - slow rates of roasting in connection with the modification transformations of quartz.

It is of practical and theoretical interest to use dehydrated clay as a non-plastic component of the molding mixture (leaner). Dehydrated clay (or low-combusted chamotte) [10] is burned at a temperature of $600-800{ }^{\circ} \mathrm{C}$, without leading to sintering, as a result of which the clay loses its plasticity and becomes a waste material. It is crushed and injected into the mass like ordinary chamotte. During the firing of products, the shrinkage of such leaner and binding clay occurs simultaneously, thereby reducing the gap between the grains of the leaner and the clay particles. As a result, the products are more dense and strong. The disadvantage is a greater shrinkage compared to products in which the claybased chamotte is used as a leaner, burned at $1000{ }^{\circ} \mathrm{C}$.

It is known that the activity of low-burned fireclay, its temperature of dehydration, degree of dehydration, etc. influence on the quality and parameters of the manufacture of products, on its base. Dehydration of kaolinite occurs in the temperature range 475 $690{ }^{\circ} \mathrm{C}$. Minerals of the montmorillonite group are dehydrated in a wider temperature range $\left(550-760{ }^{\circ} \mathrm{C}\right)$. Removal of constitutional water in the illite group is observed in the interval $500-650{ }^{\circ} \mathrm{C}$. In this case, minerals become most chemically active, and their layered structure is preserved [10].

Clay DVK-2 was used to produce low-burned chamotte Considering that the mineral composition of this clay is micakaolinite, dehydration was carried out at a temperature of $700{ }^{\circ} \mathrm{C}$ (in air), a temperature rise rate of $6{ }^{\circ} \mathrm{C} / \mathrm{min}$, an exposure time of 30 min. Compositions of masses using low-burned chamotte and their properties after firing are given in Table. 6 .

Using 10\% low-burned chamotte (dehydrated clay) allowed to reduce water absorption in all samples, while strength and frost resistance increased. This can be explained by the greater activity of the dehydrated clay at $700{ }^{\circ} \mathrm{C}$, in comparison with the chamotte burned at $1000{ }^{\circ} \mathrm{C}$. The microstructure of sample 17 is shown $\mathrm{n}$ Fig. 1.

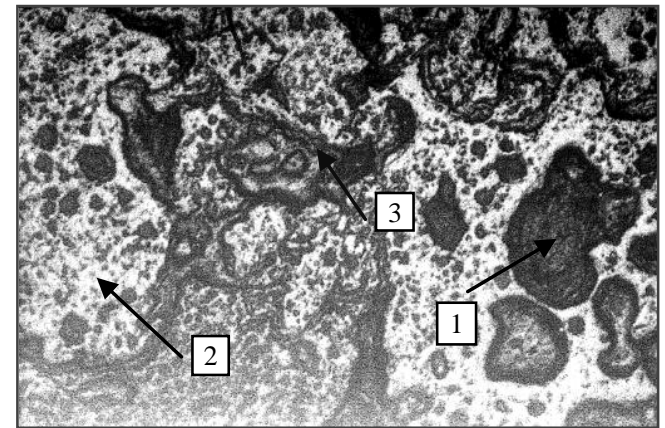

Fig. 1: Microstructure of the sample 17. Reflected light. Magnification $80^{\mathrm{x}}: 1$ - seed of chamotte, 2- mullitized glass phase, 3-pore

According to petrographic studies, a mullitized glass phase in an amount of 55 - $60 \%$ with needle-shaped small crystals of mullite is observed in the sample under study. It is determined that the sample is dense, there are no large cracks along the borders of the chamotte, pores are small with a size of $4-10 \mu \mathrm{m}$.

Table 6: Composition and properties of samples of chamotte mass with the use of low-fire chamotte

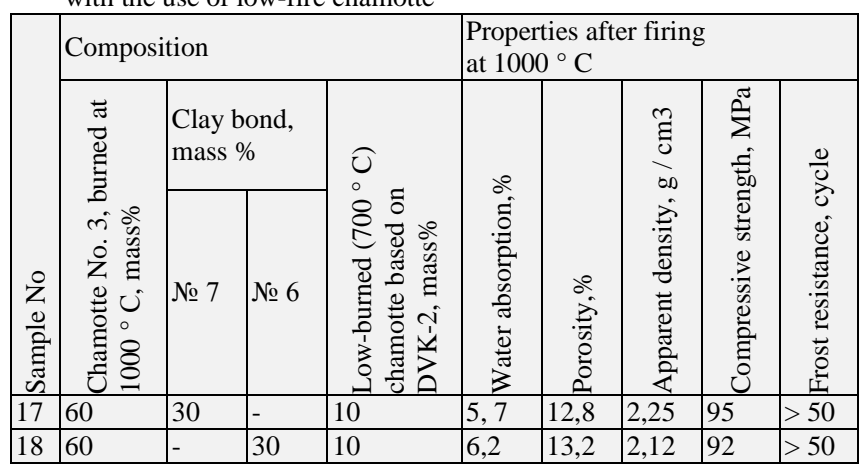

The introduction of $10 \%$ dehydrated clay of DVK-2 led to intensification of the formation of the mullitized liquid phase, reduction of shrinkage cracks in the binding clay around the seeds of chamotte and, as a result, increased frost resistance. Due to the increase in the amount of melt, the diameters of dangerous pores decreased, went into non-hazardous.

Mullite, crystallized from the melt, affects its viscosity, preventing pyroplastic deformation during roasting and, in the final result, contributes to improving the strength characteristics of the products.

\subsection{Forming Masses for Coroplastic}

For the manufacture of sculptural soft models (regardless of what material the sculpture itself will be made of), plastic materials are used: various sculptured plasticine, waxes and molding masses based on clay. Molding by hand from clay is called coroplastics.

In order to save expenses on auxiliary materials for making soft models for large sculptures, so-called sculpted clays are used, which are much cheaper than sculptural clay.

The color of the sculpted clay is of great importance. You cannot sculpture a model of dark clay for products made of light materials, because found black and shade ratio in dark clay will lose its meaning and the light sculpture will lose its expressiveness. The same dependence is maintained in the manufacture of a soft model of light clays for dark sculpture. Therefore, light clays are used for making a model for light sculpture, and for dark ones - dark clays. To increase plasticity in sculpted clays, it is necessary to add up to $10 \%$ tannin, dextrin or a solution of soda ash. In order to increase ductility, variable freezing - thawing and other methods - are also recommended [11]. As light sculpted clays, it is recommended to use highly plastic light ash high aluminate refractory clays that are not clogged with coarse-dispersed inclusions, but only the prebaking properties of these scarce clays-high plasticity, color and purity, are taken into account. As a rule, after removal from the soft model of the gypsum form, re-sculpted clays are not used 
because of the contamination by coarse-dispersed inclusions of gypsum. From clogged sculptural clay it is impossible to perform a delicate relief or counter-relief. In the conditions of sculptural workshops there are often no conditions for removing coarsedispersed inclusions, so the question arises of finding an analogue of these clays with the same pre-burning properties, but cheap and affordable.

For dark sculptured clay, it has been proposed to use beidellite clay No. 7 of the dumping horizon, which has a dark gray, almost black color.

\subsection{The Technology of Manufacturing the Molding Mass for Coroplastics}

When making a soft model, the sculptor uses a lot of different humidity. A more humid mass is used for the main volume set; for sculpting the surface fine details of the sculpture use a lot of working humidity.

The increased moisture content due to internal diffusion protects the surface layers from drying out and makes it possible to extend the working time over the surface relief without additional moistening, which is not desirable when modeling thin details. A characteristic feature in the use of mass is that the sculptor, depending on the muscular strength of the fingers, selects more or less moistened clay for coroplastic by touch.

As a result of the experiments, the optimum method for manufacturing the molding mass and its preparation for use was found. The technology is as follows:

- The clay was dried, subjected to dry grinding in a hammer mill, sieved on a No. 0056 screen.

- The resulting clay powder was poured into a container (bath, sculpture box), filling the volume by $2 / 3$. In the poured clay were made cone-shaped ( 2 or more, depending on the volume) deepening to the bottom of the tank.

- The depressions were filled with water ( $40 \%$ by weight of clay), covered with a lid and left for three days. As a result, a mass with high humidity ( $\mathrm{W}=28-32 \%$ ) was obtained in the central part of the vessel, as humidity approached the walls of the container, the humidity decreased, which allowed the sculptor to touch the weight of the necessary moisture by touch.

The developed technology of molding masses for coroplastic was tested in the conditions of sculptural workshops of the Poltava National Technical University named after Yu. Kondratyuk.

\section{Conclusions}

Formulations and technology of molding masses for large-scale products of art ceramics, baked in oxidizing and reducing environments, are developed. The developed compositions allow the sculptor to use the techniques of coroplasty.

The prospects of using low-alumina clay DVK-2 in the composition of high- and low-burned chamotte for molding ceramic masses are shown.

It has been proved that the use of dehydrated kaolinito-hydromic clay DVK-2 (low-combusted chamotte at $700^{\circ} \mathrm{C}$ ) in an amount of $10 \%$ not only reduces the shrinkage cracks around the chamotte grains, but also activates the process of low-temperature $\left(100{ }^{\circ} \mathrm{C}\right)$ liquid-phase sintering, promoting the formation of mullite, resulting in increased strength characteristics of products.

The developed technology of art large-scale ceramic products using Oposhnian clay was tested during the All-Ukrainian and International ceramic symposia on the production of garden and park sculptures.

\section{Acknowledgement}

The authors are grateful to the Ministry of Education and Science of Ukraine for the financial support of Projects No. DR. 0100U001078 and No. DR. 0103U001529, within the framework of which the research was carried out.

\section{References}

[1] Chopenko N.S, Kosyi O.P, Skorodumova O.B, Andriec Ya.O, Chistyakov A.A. (2001), Harakternye osobennosti mineralogicheskogo sostava glin neosvoennyh zon Oposhnyanskogo mestorojdeniya. Visnik Nacional'nogo tehnichnogo universitetu "Harkivs'kii politehnichnii institut", No 19, $72-78$.

[2] Chopenko N.S, Semchenko G.D, Nemec I.I. "Strukturno - mehanicheskie svoistva oposhnyanskih glin" Sb.tr. "Teoriya i praktika processov izmel'cheniya, razdeleniya, smesheniya $i$ uplotneniya", Odessa: OGMA, (2002), S. 152 - 159.

[3] Semchenko G.D., Kobec N.Yu., Chopenko N.S., Starolat E.E., Medvid' N.G., Argunov R.N. (2006), Vozmojnost' izgotovleniya shamotov iz Oposhnyanskih glin neosvoennoi zony dlya izdelii sovremennogo dizaina. Visnik Nacional'nogo tehnichnogo universitetu "Harkivs'kii politehnichnii institut", No 30, 174 - 179.

[4] Balkyavichus V, Valakyavichyus Ch, Shpokauskas A, Laukaitis A, Pyatrikaitis F. (2003), Spekaemost' legkoplavkih illito-derjaschih glin. Steklo i keramika, No 6, 18 - 21.

[5] Ignatova A.M, Chernyh M.M, Ignatov M.N (2011), Izgotovlenie hudojestvennyh i arhitekturno-dekorativnyh izdelii kamennogo lit'ya, Steklo i keramika, No 6, 31-35.

[6] Kara-sal B.K. (2007), Uluchshenie ekspluatacionnyh harakteristik keramicheskih izdelii putem izmeneniya parametrov sredy objiga, Stroitel'nye materialy, No 2, 60 - 62.

[7] Kara-sal B.K. (2007), Intensifikaciya spekaniya legkoplavkih glinistyh porod s izmeneniem parametrov sredy objiga. Steklo $i$ keramika, No 3,14-16.

[8] Abdrahimov A.V. (2006), Vliyanie jelezosoderjaschego tehnogennogo syr'ya na vyazkost' keramicheskih materialov. Ogneupory i tehnicheskaya keramika, No 2, 48 - 50.

[9] Dolgii V.P., Abdrahimova E.S., Abdrahimov V.Z. (2005), Vzaimosvyaz' poristo-kapilyarnoi struktury i morozostoikosti materiala. Ogneupory i tehnicheskaya keramika, No 4, 20-23.

[10] Yamuna A., Devanarayanan S., Latithambika M. (2002), Phasepure mullite from kaolinite. J.Amer.Ceram.Soc, 85, No 6, 1409 1413.

[11] Golovko SA. (2008), Proizvodstvo "velyurovogo kirpicha" rasshirenie assortimenta produkcii i uluchshenie ee potrebitel'skih svoistv. Stroitel'nye materialy, No 4, 17-18. 